\title{
Prof. Isabelle Tillie-Leblond
}

\author{
André-Bernard Tonnel ${ }^{1}$, Benoit Wallaert ${ }^{1}$, Arnaud Scherpereel ${ }^{1}$, Alain Didier $^{2}$ \\ and Bruno Housset ${ }^{3}$
}

Affiliations: 'Dept of Pneumology, CHRU-Lille, Lille, ${ }^{2}$ French-Language Society of Pneumology, Paris, and ${ }^{3}$ French Federation of Pneumology, Paris, France.

Correspondence: A-B. Tonnel, Dept of Pneumology, CHRU-Lille, Boulevard J. Leclercq, Lille 59037, France. E-mail: ab-tonnelachru-lille.fr

We are very sad to announce the passing of Isabelle Tillie-Leblond on March 13, 2013, at the age of 48, after a too-short but intense career. Born to a large family, she was the youngest of seven siblings, and consequently very close to her parents. Her father, a teacher in a private college, was Isabelle's model and taught his youngest daughter the great principles of life: courage, perseverance and love of others, but also cheerfulness and joie de vivre. Isabelle also knew well a close friend of the Tillie family, Albert Decourtray, a priest who was to become the Cardinal-Archbishop of Lyon; he was her godfather. After her father died, Isabelle kept a close relationship with this eminent Prelate. He remained her valued advisor, always available despite the heavy burden of his work: he always was a confidant and her mentor en humanisme.

Isabelle loved life passionately. She loved her family: her husband David, a radiologist, and her twins Nathan and François, whom she admired a lot. One of her qualities was the capacity to throw her whole being (energy, mind and heart) into what she was doing at every moment. It was also true for her patients: they rapidly trusted her, whatever the burden of the investigations or therapies, whatever the prognosis. She really represented a fascinating person for them. In other words, she loved to fight disease; for a long time, it was that of her patients, then later her own disease. It is hard not to feel that Isabelle's death is profoundly unfair. She became ill a few months after her nomination as professor. For 8 years, after each relapse, which made most of us lose hope, she returned to her patients and to all her activities with serenity, dignity, optimism and a total absence of self-pity.

Isabelle's interests were not limited to medicine. Another, less known aspect of her personality was her Social Life, such as holding important responsibilities in the city of Lille. Although she never became a member of a political party, she was Local Councillor and Deputy Mayor of the district of VaubanEsquermes. She was charged by Martine Aubry, the Mayor of Lille, with developing and reinforcing the bonds between the Town Hall and the Université Catholique de Lille, a large organisation with more than 25000 students settled in the district for which Isabelle was responsible. Thanks to her status as member of the university, Isabelle was the ideal go-between and was very much appreciated by both partners. Moreover, she not only played a role as disputant and mediator, but was also directly implicated in activities on behalf of the local population concerning the management of schools, day nurseries, cultural organisations and various events in local life. Despite a multitude of time-consuming meetings, she was always smiling, compassionate and efficient, mustering the willingness and the support of everyone. She carried out her duties in the community and the social organisation with an acute sense of justice and equity.

This positive and enthusiastic vision of others and of the world in general was present in her drawings and paintings. She said she did not know the art of painting but was always in search of a pictorial expression of what was going through her mind; her paintings were cheerful and joyful, associating round and multicoloured forms. More recently, she returned to a more figurative expression. Her attraction to painting, literature and cinema in all its aspects, as well as to cooking, surely reflected her inquiring mind, and her openness to others and modernity!

Intense is also the most suitable adjective to describe Isabelle's professional activity: Interne des Hôpitaux in 1989 , Chef de Clinique in 1993, Assistant in 1996, and she was promoted to the grade of Professeur des Universités-Médecin des Hôpitaux in April 2006. Isabelle was a young, gifted and energetic woman; she worked well and fast, and thereby easily and concomitantly supervised a wide range of activities: unceasing clinical activity including, still recently, being on duty in the Department of Pneumology; teaching always 
Prof. Isabelle Tillie-Leblond.

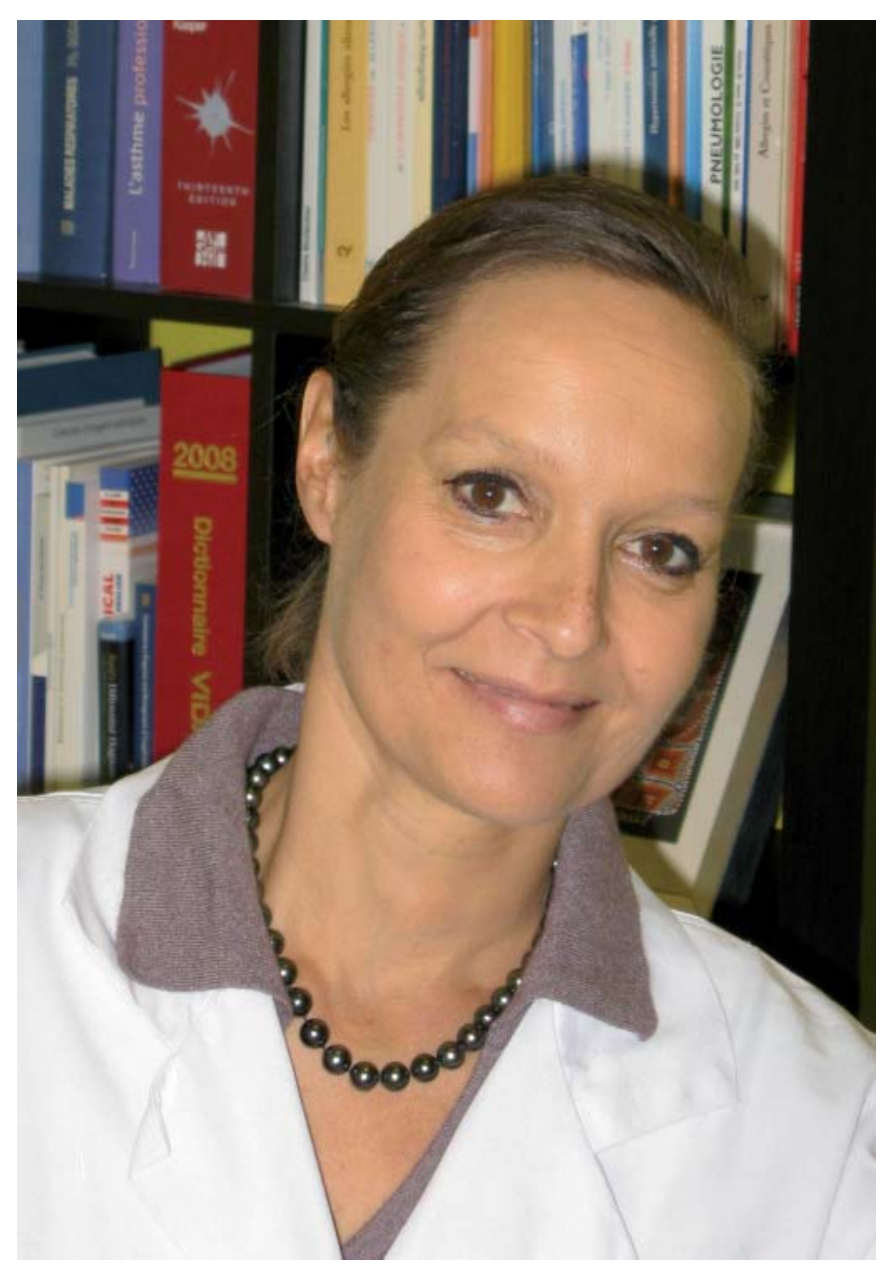

appreciated whatever the audience, be they students, chest physicians, allergists or scientists; research activity, starting with her PhD thesis in an INSERM unit at the Pasteur Institute devoted to the study of respiratory immune-allergic diseases, where she carried out research in the area of clinical pneumology. She also performed, with the cooperation of Philippe Gosset, a series of fundamental studies on the mechanisms of asthma.

Isabelle published a lot of excellent papers during her too-brief career (121 indexed in PubMed). Among the main scientific contributions, four points should be mentioned: 1) analysis of severe asthma and of status asthmaticus, the clinicobiological context of which she specified (massive influx of neutrophils, cytokine disorders, and modifications of the balance of proteases and antiproteases); 2) difficult asthma in young children in cooperation with pneumo-paediatricians in Lille and Paris, analysing the links between the early pathological alterations of the bronchial mucosa and the future of these young patients; 3) an epidemiological approach to chronic obstructive pulmonary disease (COPD), setting up a French Cohort, and its use in terms of COPD phenotypes; 4) finally, two recent and original works are worthy of citation. The first concerned a study, performed in cooperation with the group in Besançon, on a rare aetiology of hypersensitivity pneumonitis in workers exposed to metalworking fluid contaminated by Mycobacterium immunogenum. The second dealt with the role of omalizumab in the allergic bronchopulmonary aspergillosis resistant to usual therapies. In both situations, Isabelle showed her aptitude to federate energies to access an innovative result.

We would like you to remember some of Isabelle's character traits: great serenity, an innate capacity to gather people around her, a fantastic joie de vivre and her everlasting smile. With all these qualities, she had the capacity to transform the life of her friends but also the quality of life of her patients.

Isabelle, you will remain for us the image of joy, of beauty, and also of total moral and intellectual integrity. 